\title{
REVIEW
}

\section{DEACTIVATION OF PACEMAKERS AND ICDS AT THE END OF LIFE}

\author{
Marie Macková \\ Department of Midwifery and Health and Social Work, Faculty of Health Studies, University of Pardubice, Czech Republic
}

Received January 5, 2015; Accepted March 27, 2015. Copyright: This is an open access article distributed under the terms of the Creative Commons Attribution International License (CC BY). http://creativecommons.org/licenses/by/4.0/

\begin{abstract}
Aim: The aim of the present study was to seek out expert knowledge concerning the direct experience of care providers of the deactivation of pacemakers or ICDs in patients in the terminal stage of illness. Another goal was to describe the possibilities of deactivation of pacemakers and ICDs in the Czech Republic. Design: The research had the character of a systematic overview. Methods: Articles focusing on the problem area of interest were searched by means of a systematic trawl through various databases using the relevant terms. The search was limited to articles in English issued between 2000 and 2013 . Results: In total, five papers satisfying the basic criteria were found. Conclusion: The deactivation of pacemakers and ICDs in patients in the terminal stage of illness is a topic that continues to be overlooked. Studies focusing on care providers' direct experience of deactivation of the two devices in patients in the terminal stage are exceptional. However, with respect to the increasing number of patients with implanted pacemakers and ICDs, this problem area should be addressed.
\end{abstract}

Keywords: pacemaker, ICD, palliative care, deactivation, practice.

\section{Introduction}

The history of persistent cardiac pacing is now more than fifty years old. It has become a routine method of treating symptomatic or hemodynamically significant arrhythmias. Contemporary indications for this treatment extend into the area of stimulative influencing of chronic cardiac insufficiency (Gregoratos et al., 2002, p. 1703-1719).

Pacemaker technology has undergone massive development since the 1960's. Pacemakers are smaller, lighter, far more user-comfortable and more resistant to electromagnetic interference. They consist of a battery and electronic circuits stored in a titanium casing. If the pacemaker does not detect a sufficiently strong electrical signal from the patient's heart, it emits a short electrical impulse at low voltage into the heart muscle. More than 50 percent of implanted pacemakers can modify the frequency of emitted signals according to the patient's physical activity. Most pacemakers are implanted under local anaesthesia and placed under the collarbone, between the skin and pectoral musculature. Leads protrude from the pacemaker extending into the heart. Sometimes the pacemaker is implanted in the

Corresponding author: Marie Macková, Department of Midwifery and Health and Social Work, Faculty of Health Studies, University of Pardubice, Studentská 95, Pardubice, Czech Republic, email: marie.mackova2@upce.cz. outer cardiac wall. A pacemaker cannot restore a patient's heart function in the event of a cardiac arrest (Korpas, 2011). Pacing functions are also integrated in implantable cardioverter defibrillators (ICD). These systems have a shorter history of clinical use than pacemakers but the number of implantations continues to rise every year. ICDs mainly serve to treat life-threatening fast arrhythmias, an example of which is ventricular fibrillation when the heart quivers and stops pumping blood. This has a similar effect to cardiac arrest and is generally referred to as circulatory arrest. An ICD will detect this arrhythmia and emit an electrical impulse after a short time interval. This impulse runs between the electrode in the right ventricle and the device body located in the subcutis and will discharge the entire heart for an instant, interrupting ventricular fibrillation. A normal heart rhythm will subsequently resume. The ICD can also treat other arrhythmias such as ventricular tachycardias, when the heart beats very rapidly and the patient has low blood pressure or loses consciousness. In these cases, the ICD can often interrupt the arrhythmia by rapid stimulation without an electrical impulse. The ICD device is implanted in patients at high risk of life-threatening arrhythmias. Most suffer from ischemic heart disease, frequently including patients following myocardial infarction with cardiac arrest. Originally, ICDs were only implanted in patients who had already suffered from and survived circulatory arrest. In such cases, the 
treatment is a so-called 'secondary prevention' of sudden cardiac death. Another group of patients have not yet suffered arrhythmia but are known to have a high risk of arrhythmia. Indication was also extended to these precisely defined groups of patients. Such cases are regarded as primary prevention of sudden death (Bristow et al., 2004, p. 2140-2150). In 2002, there were more than three million people with a pacemaker or ICD in the United States alone (Wood, Ellenbogen, 2002, p. 2136-2138). 8,000 pacemakers and 3,000 ICDs are implanted every year in the Czech Republic (Šnorek, Bulava, 2014). The increasing number of patients with implanted pacemakers or ICDs, however, also means increased risk of a combination of heart and oncological diseases. If a patient is dying of an oncological disease, an implanted pacemaker or ICD may result in prolonged death.

\section{Aim}

The aim of the present study was to seek out expert knowledge concerning direct experience of care providers of the deactivation of pacemakers or ICDs in patients in the terminal stage of illness. Another goal was to describe the possibilities of deactivation of pacemakers and ICDs in the Czech Republic.

\section{Methods}

\section{Design}

The research had the character of a systematic overview.

\section{Eligibility criteria}

The following selection criteria were defined based on the research question: full text of article, in English, published between 2000 to 2013 in peerreviewed magazines and expert studies. Abstracts and articles issued in other languages, or outside the delimited time frame, non peer-reviewed magazines, ethical discourses, and research reviews were excluded.

\section{Sources}

Expert licensed databases and freely accessible databases were used to obtain relevant sources. Concrete databases OVID SP (EBM Reviews, EMBASE, MEDLINE), Science Direct, Scopus, Web of Science (WoS) represented significant sources.

\section{Search}

The searching of relevant sources took place between January-June 2014. English was selected as the search language. The year 2000 was selected as the starting point for the stipulated search period as the area of concern is subject to rapid change and older studies may no longer reflect the current situation. The full texts of articles written by experts were compiled in the search period (2000-2013). The search focused on publications in the form of peerreviewed contributions describing research into the specified topic, of bona fide scientific quality. The following key words were used to search the specified databases: pacemaker, ICD, end of life, palliative care, deactivation. Due to the complexity of finding relevant sources, different combinations of the above-stated key words were used while applying Boolean operators. A total of 73 communications were found corresponding to the selection criteria.

\section{Studies selection and data analysis}

After studying the various peer-reviewed articles, those not related to the topic of concern or not meeting the selection criteria were excluded. Subsequently, a systematic overview of studies featuring the deactivation of pacemakers or ICDs in patients in the terminal stage of illness was created. The process of study selection is described in Scheme 1.

\section{Results}

Few researchers focused on the question of care providers' experience of pacemaker or ICD deactivation in patients in the terminal stage of illness. Studies on this topic usually focus on the hypothetical considerations of deactivating both devices or involve ethical discourses.

We were able to obtain only five studies focusing on direct experience of deactivation of pacemakers or ICDs. An overview of these studies, conforming to the selection criteria is specified in Table 1.

\section{Discussion}

As the number of patients with pacemakers or ICDs increases, interest in the problem of the deactivation of these devices in case of terminal conditions also rises. However, most studies focus on the opinions of doctors, patients or manufacturers of the above mentioned devices. Very few studies describing care providers' own experience of pacemaker or ICD deactivation in patients with terminal conditions have been published, which may be due to the fact that many countries perceive pacemaker or ICD deactivation as euthanasia, i.e. as an illegal act.

In practice, ICDs are deactivated more frequently than pacemakers (Morrison et al., 2010, p. 1-7). On the one hand, this fact might appear surprising because there are more patients with pacemakers than with ICDs. 


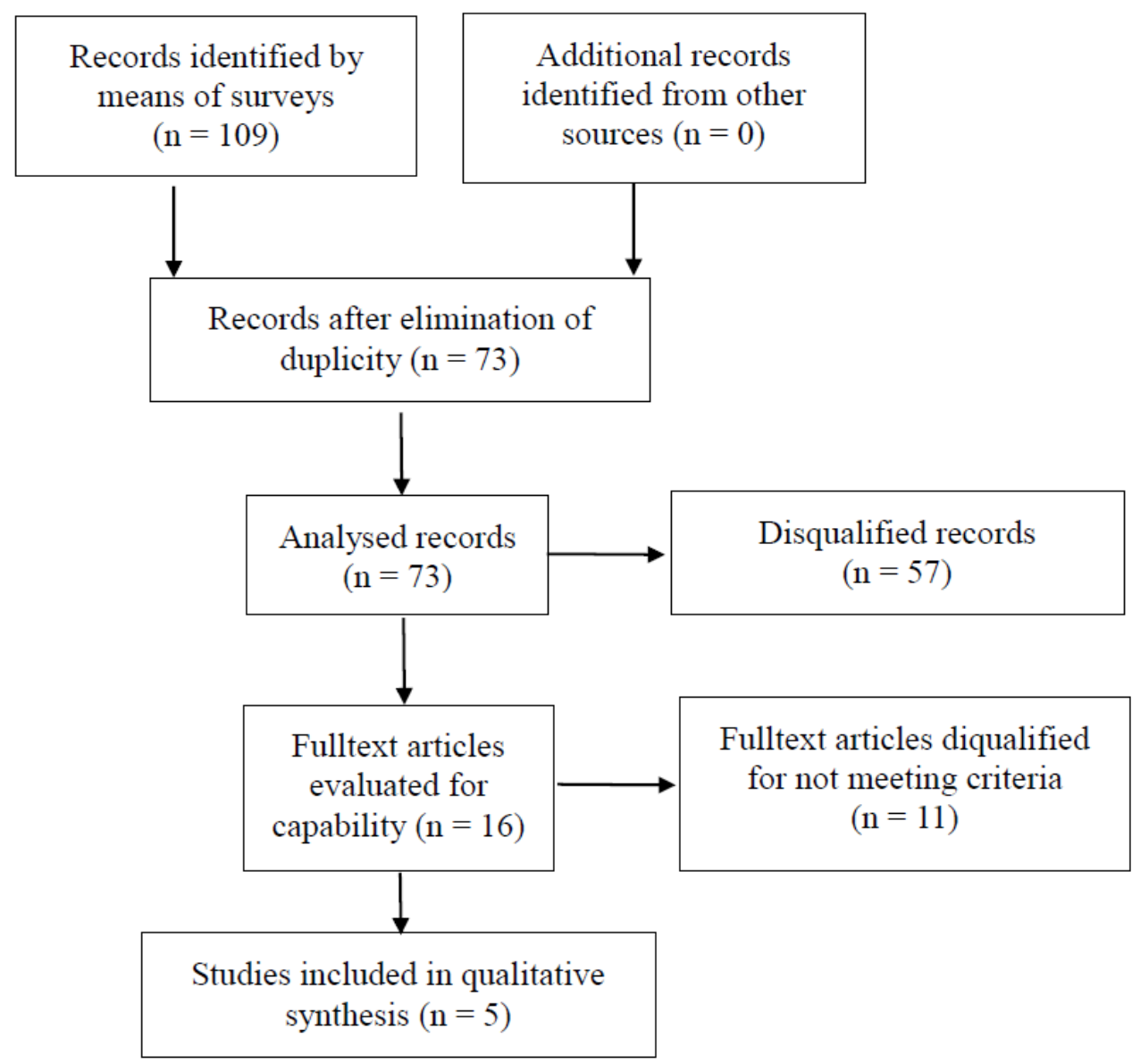

Scheme 1 Overview of studies selection

Table 1 Overview of studies related to deactivation of pacemakers and ICDs in terminal patients $(n=5)$

\begin{tabular}{|c|c|c|c|}
\hline Author & Purpose & Method & Results \\
\hline Köbe et al. (2012) & $\begin{array}{l}\text { To describe when and under } \\
\text { what conditions ICD was } \\
\text { deactivated. }\end{array}$ & $\begin{array}{l}\text { Prospective study of } 5 \\
\text { patients after ICD } \\
\text { deactivation. }\end{array}$ & $\begin{array}{l}\text { Three deactivations due to } \\
\text { end of battery life, one } \\
\text { deactivation upon patient } \\
\text { request, one deactivation } \\
\text { upon patient request, who } \\
\text { fulfilled patient's advance } \\
\text { directives. }\end{array}$ \\
\hline Morrison et al. (2010) & $\begin{array}{l}\text { To describe how often } \\
\text { pacemakers and ICDs are } \\
\text { deactivated. }\end{array}$ & $\begin{array}{l}\text { Quantitative method. } 112 \\
\text { respondents were asked } \\
\text { about their experience of } \\
\text { deactivation. }\end{array}$ & $\begin{array}{l}\text { Request for pacemaker } \\
\text { deactivation is more } \\
\text { frequent. The reason for the } \\
\text { rejection of prolonged death. } \\
\text { Applications for ICD } \\
\text { deactivation justified on } \\
\text { refusing resuscitation. }\end{array}$ \\
\hline Mueller et al. (2008) & $\begin{array}{l}\text { To describe how often } \\
\text { pacemakers and ICDs are } \\
\text { deactivated. }\end{array}$ & $\begin{array}{l}\text { Quantitative method. } 787 \\
\text { respondents were asked } \\
\text { about their experience of } \\
\text { deactivation. }\end{array}$ & $\begin{array}{l}\text { Request for pacemaker or } \\
\text { ICD deactivation is usual in } \\
\text { terminal patients. }\end{array}$ \\
\hline Bogan et al. (2006) & $\begin{array}{l}\text { To describe casuistry of ICD } \\
\text { deactivation. }\end{array}$ & Casuistry. & $\begin{array}{l}\text { ICD deactivation upon } \\
\text { polymorbid patient's request. }\end{array}$ \\
\hline $\begin{array}{l}\text { Nambisan, Chao } \\
(2004)\end{array}$ & $\begin{array}{l}\text { To describe casuistry of ICD } \\
\text { deactivation. }\end{array}$ & Casuistry. & $\begin{array}{l}\text { ICD deactivation in patient } \\
\text { in terminal stage of lung } \\
\text { tumor. }\end{array}$ \\
\hline
\end{tabular}


On the other hand, we must appreciate the impact of an implanted pacemaker or an implanted ICD on a dying patient. Pacemakers usually prolong the actual phase of dying but do not cause the patient any pain. ICDs may also prolong the actual dying phase and, in addition, may inflict suffering on the patient. Goldstein et al. (2004, p. 835-838) state that repeated impulses are painful for the patient and may even cause the skin in the surrounding area of the implanted ICD to heat up.

In their study, Morrison et al. (2010, p. 1-7) further explored how frequently respondents are confronted with the need to deactivate a pacemaker or ICD in practice. Most respondents were hospitalized in hospices or palliative care units. On average, respondents reported that they encountered the need to deactivate ICDs twice a year, and pacemakers once a year. Protocols focusing on the deactivation of pacemakers or ICDs were only available to 10 percent of the respondents. Discussion on pacemaker or ICD deactivation was initiated by respondents on average once a year. Patients or their families also initiated discussion regarding pacemaker or ICD deactivation once a year.

Deactivation may take place in two circumstances. In the first, the battery in the implanted device is naturally depleted and, based on the patient's clinical condition (usually poly-morbidity and terminal condition), the implantation of a new device is not performed. In the second, the device is deactivated at the patient's or, if they are no longer able to personally express this wish due to coma or severe degree of Alzheimer's disease etc, their family's behest (Köbe et al., 2012, p. 1291).

Deactivation of both devices is not necessarily the expression of the patient's wishes concerning end of life care (so-called 'advance directives'). Goldstein et al. (2004, p. 835-838) state that an ICD is often deactivated a few days or hours before death when there is no time to discuss this action with the patient or their family. Bogan et al. also point out the need to discuss pacemaker or ICD deactivation with patients or their families in time. This discussion involves both the collaboration of cardiologists and primary doctors, and doctors at hospices or palliative units. According to Mueller et al. (2008, p. 560-568), requests for pacemaker or ICD deactivation are common in patients in a terminal condition. Deactivation is usually carried out by an engineer provided by the device manufacturer.

In the Czech Republic, deactivation of pacemakers and ICDs can be viewed in the light of two fundamental documents. The first is the Biomedicine Convention and the second the Medical Service Act.
The enactment of the Biomedicine Convention in 2001 supported patients' right to self-determination and, thus, previously unknown institutes were implemented in the Czech legal system - advance directives and vicarious consent of persons delegated as such by law (not necessarily a guardian). These institutes, however, were rarely used in practice because more detailed legal regulations were lacking until the Medical Service Act, effective since April 2012, introduced them. Unfortunately, it did not state the mutual relationship between advance directives and vicarious decision-making. This deficit was only removed by Act No. 89/2012 Coll. of the new Civil Code.

Advance directives, earlier regulated by Article 9 of the Biomedicine Convention, were worked out in detail in Section 36 of the Health Service Act. They enable the patient to express their consent or opposition to future treatment in advance. Besides a general definition of the legal institute, this paragraph also defines the conditions that the patient's previously expressed directive must meet in order to be legally binding.

"Advance directives must be in written form and be furnished with the patient's legalized signature. The advance directive must also include the patient's written instruction on the consequences of his decision, either expressed by a general practitioner or another attending physician in healthcare area, related to the advance directive." (Medical Service Act, Section 36) A legalized signature, however, is not required if the patient expresses such directives in the course of their hospitalization. In such a case, the patient's advance directive will be recorded in the medical records along with the patient's, medical employee's and witness's signatures.

Paragraph 5, Section 36 determines situations in which a physician is not required to or must not respect a patient's advance directive. Advance directives "are not obliged to be respected if the provision of medical services related to these directives has developed so significantly since the time of the directives' expression that it can be reasonably anticipated that the patient would agree to their provision." Physicians must not respect those advance directives that "incite the application of such methods which actively cause death or by the fulfilment of such a directive could endanger other persons or if, in the time when the advance directives were not available to the care provider, such medical acts were initiated the interruption of which would actively cause death." Section 36 is then terminated by paragraph 6 , rejecting the possibility of the 
expression of such advanced directives by minors or legally incapacitated patients.

Based on the information above, it can thus be stated that in the Czech legal system, the deactivation of pacemakers or ICDs is illegal for two reasons: patients are not fully informed about the results of deactivation because this option is not even discussed with them (Herman et al., 2013), and deactivation is perceived as a procedure that actively causes death.

\section{Limitation of study}

Our study only includes material published in English and publicly available in databases. The study does not include material in any languages other than English and in any form other than electronic.

\section{Conclusion}

Deactivation of pacemakers and ICDs in patients in the terminal stage of illness remains a neglected topic. Studies focusing on care providers' direct experience of deactivation of the two devices in patients in the terminal stage are exceptional. However, with respect to the increasing number of patients with implanted pacemakers and ICDs, this problem area should be addressed.

To enable pacemaker or ICD deactivation in the Czech Republic, the following steps are recommended: before actual treatment indication using a pacemaker or ICD, treatment should be discussed in detail with the patient, including complications and possible deactivation. The position of ethics consultant should be introduced into Czech hospitals. Finally, professional societies should also take a position on this problem area.

\section{Ethical aspects and conflict of interest}

All bibliographical sources used have been cited. The author declares that the present study involves no conflict of interests.

\section{References}

Bogan C, Kieran T, O'Brien T, Fahy G. Deactivation of an implantable cardioverter defibrillator in a dying patient. Irish medical journal. 2006;99(5):155.

Bristow MR, Saxon LA, Boehmer J, Krueger S, Kass DA, De Marco T, Carson P, DiCarlo L, DeMets D, White BG, DeVries DW, Feldman AM. Cardiac-resynchronization therapy with or without an implantable defibrillator in advanced chronic heart failure. New England Journal of Medicine. 2004;350:2140-2150.

Česko. Úmluva na ochranu lidských práv a důstojnosti lidské bytosti $\mathrm{v}$ souvislosti s aplikací biologie a medicíny ze dne 1 . 10. 2001 (Úmluva o biomedicíně). Sbirka mezinárodních smluv. 2001;44:1897-1919. (in Czech)

Česko. Zákon č. 372 ze dne 1. 4. 2012 o zdravotních službách a podmínkách jejich poskytování (zákon o zdravotních službách). Sbirka zákonů České republiky. 2012;131:4730 4801. (in Czech)

Česko. Zákon č. 89 ze dne 3. 2. 2012 nový občanský zákoník. Sbirka zákoni̊ České republiky. 2012;33:1025-1368. (in Czech)

Gregoratos G, Abrams J, Epstein AE, Freedman RA, Hayes DL, Hlatky MA, Kerber RE, Naccarelli GV, Schoenfeld MH, Silka MJ, Winters SL. ACC/AHA/NASPE 2002 Guideline update for implantation of cardiac pacemakers and antiarrhythmia devices - summary article: a report of the American College of Cardiology/American Heart Association Task force on practice guidelines (ACC/AHA/NASPE Committee to update the 1998 Pacemaker guidelines). Journal of the American College of Cardiology. 2002;40(9):1703-1719.

Goldstein NE, Lampert R, Bradley E, Lynn J, Krumholz HM. Management of implantable cardioverter-defibrillators: results of patients surveys. Annals of internal medicine. 2004;141(11):835-838.

Herman D, Stros P, Curila K, Kebza V, Osmančík P. Deactivation of implantable cardioverter-defibrillators: results of patient surveys. Europace. 2013;15(7):963-969.

Korpas, D. Kardiostimulační technika. 1. vyd. Praha: Mladá Fronta; 2011. (in Czech)

Köbe J, Wasmer K, Reinke F, Eckardt L. Deactivation of implanted cardioverter-defibrillators at the end of life in the setting of an uutpatient clinic. Journal of Palliative Medicine. 2012;15(12):1291-1291.

Morrison LJ, Calvin AO, Nora H, Porter Storey C Jr. Managing Cardiac devices near the end of life: A Survey of hospice and palliative care providers. American Journal of Hospice and Palliative Medicine. 2010;27(8):545-551.

Mueller PS, Jenkins SM, Bramstedt KA, Hayes DL. Deactivating implanted cardiac devices in terminally ill patients: practices and attitudes. Pacing and clinical electrophysiology. 2008;31(5):560-568.

Nambisan V, David Ch. Dying and defibrillation: a shocking experience. Palliative medicine. 2004;18(5):482-483.

Ptáček R, Bartůněk P. Etické problémy medicíny na prahu 21. stoleti. 1. vyd. Praha: Grada; 2014. (in Czech)

Šnorek M, Bulava A. MR kompatibilní kardiostimulátory a implantabilní kardiovertery-defibrilátory. Vnitřni Lékařství. 2014;60(2):123-127. (in Czech)

Wood MA, Ellenbogen KA. Cardiac pacemakers from the patient's perspective. Circulation. 2002;105(18):2136-2138. 